\title{
Pengaruh Rasio Likuiditas, Rasio Solvabilitas, Dan Rasio Aktivitas Terhadap Pertumbuhan Perusahaan
}

\author{
Nida Putri Rahmayanti ${ }^{1}$ \\ nidaputrirahmayanti@gmail.com \\ Sekolah Tinggi Ilmu Ekonomi Pancasetia Banjarmasin \\ Susmita Dian Indiraswari ${ }^{2}$ \\ susmita@unikama.ac.id \\ Universitas PGRI Kanjuruhan Malang
}

\begin{abstract}
:
Penelitian ini mempunyai tujuan yakni menguji pengaruh antara rasio likuiditas, rasio solvabilitas dan rasio aktivitas terhadap pertumbuhan laba pada perusahaan transportasi yang tercatat di BEI. Populasinya adalah seluruh perusahaan yang tergabung dalam BEI. Sampel penelitiannya adalah seluruh perusahaan sektor transportasi di BEI tahun 2019 dan 2020 dengan menggunakan purposive sampling.

Metodenya menggunakan uji regresi linier berganda. Hasil dari penelitian ini Tidak terdapatnya pengaruh secara parsial rasio likuiditas, rasio solvabilitas terhadap pertumbuhan perusahaan. Terdapatnya pengaruh secara parsial rasio aktivitas terhadap pertumbuhan perusahaan, serta tidak terdapatnya pengaruh secara simultan antara rasio likuiditas, rasio solvabilitas, dan rasio aktivitas terhadap pertumbuhan perusahaan.
\end{abstract}

Keywords: ratio likuiditas, ratio solvabilitas, rasio aktivitas 


\section{PENDAHULUAN}

Setiap perusahaan pasti menginginkan pertumbuhan perusahaan yang bagus seiring dengan tingkat yang semakin cepat dalam pertumbuhannya juga akan terindikasi perusahaan sedang mengadakan perluasan pasar baru. Suatu perusahaan dikatakan mencapai kesuksesannya atau keberhasilannya dan dapat mengalahkan pesaing-pesaingnya, dengan salah satu indikatornya dapat menumbuhkan laba pada perusahaan tersebut (Virgianthi, Yuesti, \& Dewi, 2019). Oleh sebab itu, dalam keberlangsungan perusahaan yang paling penting dan yang sangat diharapkan oleh pihak internal maupun eksternal adalah pertumbuhan perusahaan. Dikarenakan dalam pertumbuhan yang bagus akan memberi simbol pada perusahaan berkembang. Selain itu, ada rasio likuiditas yang dimana dipergunakan untuk mengukur tingkat kapabilitas perusahaan dalam melunasi hutangnya.

Rasio berikutnya solvabilitas juga penting karena menunjukkan arus kas perusahaan, dan yang terakhir yakni rasio aktivitas menjelaskan cara pemda dalam merealisasikan pendapatan asli didaerahnya. Populasi pada penelitian adalah perusahaan transport tahun 2019-2020 yang terdaftar pada Bursa Efek Indonesia. Perekonomian di Negara Indonesia didukung oleh beberapa sektor, salah satunya sector transportasi. Sector transportasi ini mengalami guncangan dahsyat semenjak terjadi pandemic, sehingga persaingan dalam industri transportasi sangat ketat. Seperti adanya promo dan potongan harga (Nyale, 2020).

Perusahaan transport yang berguna untuk memberi kemudahan kegiatan manusia dalam melakukan aktivitas sehari-hari, juga dikatakan sebagai alat dalam melancarkan proses perpindahan barang atau manusia dari satu tempat ke tempat lainnya. Bahkan, juga sebagai alat yang dapat membantu perkembangan dna pertumbuhan pembangunan di daerah tertentu. Kendati demikian, permasalahan pun muncul pada kondisi PT Garuda Indonesia. Kondisi keuangan maskapai ini terpuruk pada akibat hantaman covid 19. Hutang perseroan semakin menumpuk hingga 37 
mencapai Rp 70 Triliun, kemungkinan terus bertambah Rp 1 Triliun setiap bulan (Kompas.com).

Tak hanya pada transportasi udara saja, darat pun juga terkena dampaknya seperti angkutan bus yang juga mabruk. Omzet dari angkutan darat sudah turun $70 \%$ $80 \%$, sementara angkutan logistic juga turun sampai 50\% (cnbcindonesia.com). Selain itu, sector pelayaran pun juga sedang menghadapi tantangan berat akibat pandemic, yang mana sector laut mengalami penurunan volume kargo, baik ekspor impor hingga $14-18 \%$. Akibat dari penurunan ini banyak perusahaan yang bangkrut.

\section{TINJAUAN PUSTAKA}

\section{Teori Sinyal (Signalling Theory)}

Menurut Brigham \& Houston (2011:186), teori sinyal yaitu suatu action yang harus dilakukan oleh manajemen. Di dalam suatu perusahaan akan memberi petanda kepada investor tentang cara manajemen melakukan penilaian prospek perusahaan. Sinyal yang bagus bagi perusahaan menjadi hal yang sangat berpengaruh dalam pengambilan keputusan investor ataupun manajemen dalam menanamkan atau membeli saham di perusahaan tersebut. Signalling theory ini memiliki tujuan untuk membantu perusahaan, pemilik, eksternal perusahaan untuk mengurangi kesenjangan informasi mengenai kualitas atau integritas informasi laporan keuangan (Tibiletti, Marchini, Gamba, \& Todaro, 2021).

\section{Rasio Keuangan}

Rasio keuangan berdasarkan sumber data yang dipergunakan untuk membedakan menjadi beberapa rasio. Adapun rasionya adalah neraca, laba rugi, dan laporan keuangan. Adapun untuk tujuan dari rasio keuangan itu sendiri dapat klasifikaskan menjadi beberapa rasio dan rasio yang diperuntukkan pada penelitian ini ada rasio likuiditas, rasio solvabilitas, dan rasio efektifitas. 


\section{Pertumbuhan Perusahaan}

Pertumbuhan perusahaan atau pertumbuhan laba merupakan kenaikan atau penurunan laba setiap tahunnya (Sari \& Sudjarni, 2015). Pertumbuahan ini juga disebut sebagai kenaikan laba yang dimiliki perusahaan dibandingkan dengan pertumbuhan sebelumnya. Serta bagaimana prediksi pertumbuhan pada perusahaan sebagai dasar untuk menilai bagaimana kinerja suatu perusahaan tersebut (Syahdeni \& Hrp, 2021).

\section{METODE PENELITIAN}

\section{Populasi dan Sampel}

Populasi adalah semua perusahaan yang tergabung dalam BEI. Sampelnya adalah semua perusahaan sektor transportasi di BEI tahun 2019 dan 2020. Kriteria sampel antara lain: a) Perusahaan yang terdaftar di BEI tahun 2019-2020, b) Perusahaan transportasi yang menerbitkan laporan keuangan tahun 2019 - 2020, c) Laporan keuangan yang dimuat dengan mata uang rupiah

\section{KERANGKA KONSEP PENELITIAN}

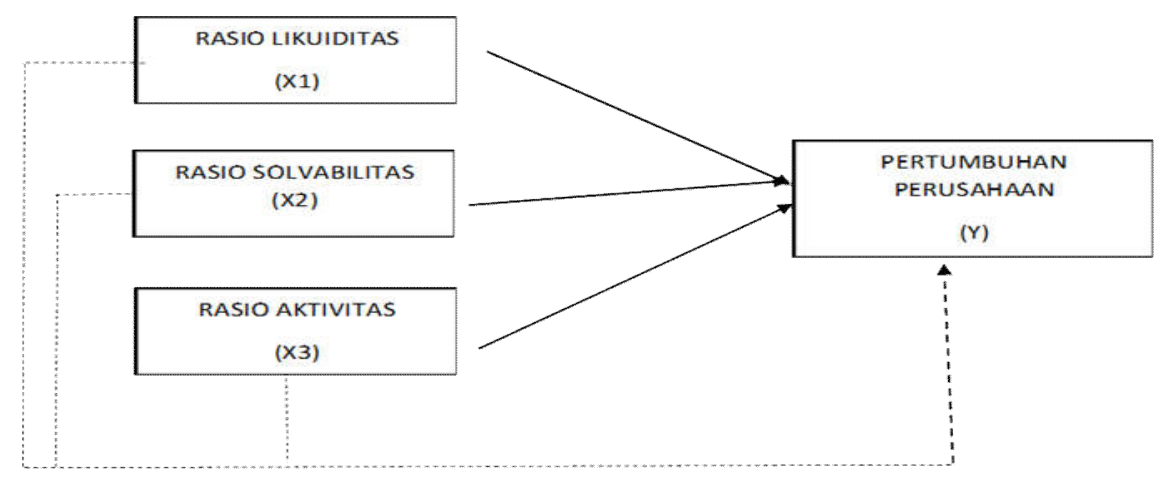

\section{Gambar 1.1. Kerangka Pemikiran}

Ket:

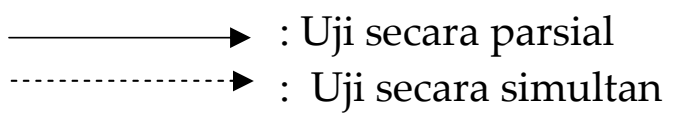




\section{HIPOTESIS PENELITIAN}

Berdasarkan dengan kerangka pemikiran di atas, hipotesis penelitian ini dirumuskan sebagai berikut:

H1 : Rasio likuiditas berpengaruh secara parsial terhadap pertumbuhan perusahaan.

H2 : Rasio solvabilitas berpengaruh secara parsial terhadap pertumbuhan perusahaan.

H3 : Rasio aktivitas berpengaruh secara parsial terhadap pertumbuhan perusahaan.

H4 : Rasio likuiditas, solvabilitas, dan aktivitas berpengaruh secara simultan terhadap pertumbuhan perusahaan.

\section{HASIL PENELITIAN}

Tabel 1

One-Sample Kolmogorov-Smirnov Test

\begin{tabular}{|ll|r|r|r|r|}
\hline & & $\begin{array}{c}\text { RASIO } \\
\text { LIKUIDITAS }\end{array}$ & $\begin{array}{c}\text { RASIO } \\
\text { SOLVABILIT } \\
\text { AS DER }\end{array}$ & $\begin{array}{c}\text { RASIO } \\
\text { AKTIVITAS } \\
\text { TATO }\end{array}$ & $\begin{array}{c}\text { PERTUMBU } \\
\text { HAN } \\
\text { PERUSAHAA } \\
\mathrm{N}\end{array}$ \\
\hline $\mathrm{N}$ & & 62 & 62 & 62 & 62 \\
Normal & Mean & 1.426826 & 1.481279 & .481890 & .034192 \\
Parameters ${ }^{\mathrm{a}, \mathrm{b}}$ & Std. Deviation & 1.3364965 & 2.7988661 & .4218634 & .2338287 \\
Most Extreme & Absolute & .201 & .313 & .215 & .185 \\
Differences & Positive & .201 & .266 & .215 & .185 \\
& Negative & -.166 & -.313 & -.181 & -.134 \\
& .763 & .594 & .720 & .466 \\
Kolmogorov-Smirnov Z & .605 & .872 & .667 & .982 \\
\hline Asymp. Sig. (2-tailed) & \multicolumn{3}{|c}{} \\
\hline
\end{tabular}

a. Test distribution is Normal.

b. Calculated from data.

\section{Sumber: Output SPSS 25, (September 2021)}

Metode analisis data sangatlah diperlukan dalam melakukan sebuah penelitian.

Peneliti menggunakan perangkat lunak SPSS 25. Selain itu, uji statistic yang digunakan yaitu uji normalitas data yang berfungsi mengetahui data apakah berdistribusi normal atau tidak yang menggunakan uji one sample Kolmogorov-smirnov. Adapun untuk pengujian hipotesis menggunakan uji regresi linier berganda dengan kriteria pengujian hipotesis. Jika nilai probabilitas $>$ dari taraf signifikansi (Sig.2-tailed>0,05), $\mathrm{H}_{0}$ diterima dan $\mathrm{H}_{1}$ ditolak. 


\section{Uji Statistik $\mathbf{t}$}

Uji t-statistik dilakukan untuk melihat signifikansi dari pengaruh variabel independent secara individu ke variabel dependen.

\section{Tabel 2. Hasil Pengujian t-statistik}

\section{Coefficients $^{a}$}

\begin{tabular}{|c|c|c|c|c|c|c|}
\hline \multirow{2}{*}{\multicolumn{2}{|c|}{ Model }} & \multicolumn{2}{|c|}{$\begin{array}{l}\text { Unstandardized } \\
\text { Coefficients }\end{array}$} & \multirow{2}{*}{\begin{tabular}{|c}
$\begin{array}{c}\text { Standardize } \\
\mathrm{d} \\
\text { Coefficients }\end{array}$ \\
Beta
\end{tabular}} & \multirow[b]{2}{*}{$\mathrm{t}$} & \multirow[b]{2}{*}{ Sig. } \\
\hline & & B & Std. Error & & & \\
\hline \multirow[t]{7}{*}{1} & (Constant) & -.041 & .055 & & -.740 & .462 \\
\hline & RASIO LIKUIDITAS & .018 & .023 & .101 & .773 & .443 \\
\hline & RASIO & -.012 & .011 & -.142 & -1.119 & .268 \\
\hline & SOLVABILITAS & & & & & \\
\hline & DER & & & & & \\
\hline & RASIO AKTIVITAS & .140 & .070 & .253 & 2.001 & .050 \\
\hline & TATO & & & & & \\
\hline
\end{tabular}

a. Dependent Variable: Pertumbuhan Perusahaan

Berdasarkan tabel uji t (parsial) dapat diketahui bahwa:

1. Variabel independent rasio likuiditas memiliki nilai signifikansinya 0,443. Karena nilai thitung $<$ tabel dan signifikansinya $0,443>0,050$. Sehingga hipotesis ditolak

2. Variabel independent rasio solvabilitas (DER) memiliki nilai signifikansinya 0,268 . Karena nilai thitung $<$ tabel dan signifikansinya $0,268>0,050$. Sehingga hipotesis ditolak.

3. Variabel independent rasio aktivitas (Tato) memiliki nilai signifikansinya 0,050. Karena nilai thitung $>$ ttabel dan signifikansinya $0,050=0,050$. Sehingga hipotesis diterima. 
Tabel 3. Hasil Uji F

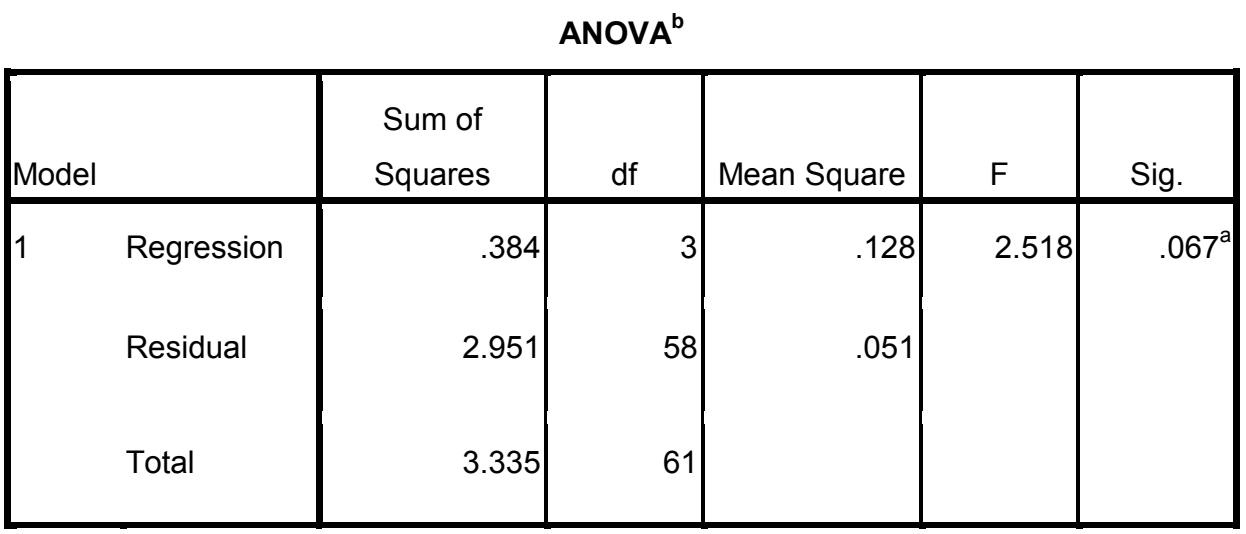

a. Predictors: (Constant), RASIO AKTIVITAS TATO, RASIO SOLVABILITAS DER, RASIO LIKUIDITAS

b. Dependent Variable: PERTUMBUHAN PERUSAHAAN

Berdasarkan table di atas, hasil uji F-statistik menunjukkan sebesar 2,518 dengan tingkat signifikansinya 0,067 di atas 0,050. Oleh karena itu tidak terdapatnya pengaruh secara simultan atau secara bersama-sama antara variabel rasio likuiditas, rasio solvabilitas, dan rasio aktivitas terhadap pertumbuhan perusahaan.

Tabel 4. Koefesien Determinasi (R square)

Model Summary

\begin{tabular}{|l|r|r|r|c|}
\hline Model & \multicolumn{1}{|c|}{$\mathrm{R}$} & R Square & \multicolumn{1}{c|}{$\begin{array}{c}\text { Adjusted R } \\
\text { Square }\end{array}$} & $\begin{array}{c}\text { Std. Error of the } \\
\text { Estimate }\end{array}$ \\
\hline 1 & $.339^{\mathrm{a}}$ & .115 & .069 & .2255594 \\
\hline
\end{tabular}

a. Predictors: (Constant), RASIO AKTIVITAS TATO, RASIO

SOLVABILITAS DER, RASIO LIKUIDITAS

Hasil uji r square menunjukkan bahawa 11,5\% variabel rasio likuiditas, variabel rasio solvabilitas, dan rasio aktivitas mempengaruhi pertumbuhan perusahaan. 
Sedangkan sisanya yaitu 88,5\% dipengaruhi oleh variabel lainnya yang tidak diteliti oleh peneliti.

\section{PEMBAHASAN}

Berdasarkan hasil pengujian di atas, H1 yaitu variabel rasio likuiditas tidak berpengaruh terhadap pertumbuhan perusahaan. Hal ini sesuai dengan penelitian dari (Aryanto, Titisari, \& Nurlaela, 2018) yang menjelaskan bahwa rasio likuiditas disebabkan tidak berpengaruh terhadap perumbuhan laba karena perusahaan memiliki total aktiva yang sangat tinggi dari pada hutang jangka pendek. Selain itu, menurut (Syafril \& Djawoto, 2020) tidak berpengaruhnya rasio likuditas terhadap pertumbuhan laba disebabkan karena perusahaan yang memiliki aktiva lancar yang sangat tinggi. Namun, tidak memberikan jaminan ketersediaan modal kerja bagi perusahaan. Disebabkan, jika hasil pengukuran rasio tinggi, juga belum dikatakan bahwa keadaan perusahaan baik dan belum ada jaminan bahwa akan dapat terbayarnya hutang perusahaan yang telah jatuh tempo karena proporsi atau distribusi aktiva lancar yang tidak menguntungkan, sehingga tidak berpengaruh terhadap kenaikan atau penurunan pada pertumbuhan laba (Panjaitan, 2018).

H2 yang menyatakan bahwa variabel rasio solvabilitas tidak berpengaruh terhadap pertumbuhan perusahaan. Penelitian ini sejalan dengan (Virgianthi et al., 2019) yang menjelaskan bahwa berapa pun besarnya rasio solvabilitas tidak akan mempengaruhi pertumbuhan perusahaan. Menurut Tibiletti et al., (2021) dikarenakan Sebagian besar perusahaan memiliki total ewuity yang sangat rendah sehingga menyebabkan perolehan rasio solvabilitas menjadi meningkat. Oleh sebab itu, rasio solvabilitas tidak berpengaruh terhadap pertumbuhan perusahaan.

H3 yang menjelaskan bahwa variabel rasio aktivitas berpengaruh terhadap pertumbuhan perusahaan. Penelitian sesuai dengan (Alfitri \& Sitohang, 2018) yang menjelaskan bahwa rasio aktivitas berpengaruh terhadap pertumbuhan perusahaan. 
Dikarenakan jika TATO mengalami peningkatan secara otomatis juga diikuti oleh pertumbuhan laba. Karena perusahaan dianggap mampu mengelola asetnya atau kekayaanya seperti menghasilkan penjualan yang efektif (Sandjaja \& Suwaidi, 2021). Selain itu pula, TATO ini akan berdampak pada peetumbuhan perusahaan disebabkan adanya kemungkinan tingkat penjualan yang tinggi sehingga akan disertai dengan biaya operasional yang tinggi pula (Alfitri \& Sitohang, 2018). Dengan demikian, TATO berpengaruh terhadap pertumbuhan perusahaan. H4 menjelaskan bahwa tidak pengaruh secara simultan antara rasio likuiditas, rasio solvabilitas, dan rasio aktivitas terhadap pertumbuhan perusahaan. Disebabkan karena dipengaruhi oleh variabel lain yang tidak dipilih sebagai variabel dalam penelitian ini.

\section{KESIMPULAN}

1. Tidak terdapatnya pengaruh secara parsial rasio likuiditas, dan rasio solvabilitas terhadap pertumbuhan perusahaan. Serta tidak terdapatnya pengaruh secara simultan antara rasio likuiditas, rasio solvabilitas, dan rasio aktivitas terhadap pertumbuhan perusahaan.

2. Terdapatnya pengaruh rasio aktivitas terhadap pertumbuhan perusahaan.

3. Penelitian memiliki keterbatasan yakni belum semua perusahaan sector transportasi menerbitkan laporan keuangannya. Untuk penelitian selanjutnya untuk mencari sektor lainnya selain sektor tranportasi dan sudah menerbitkan laporan keuangannya di Bursa Efek Indonesia, serta menambah variabel lainnya yang tidak dimasukkan dalam penelitian ini.

\section{DAFTAR PUSTAKA}

Alfitri, I. D., \& Sitohang, S. (2018). Pengaruh Rasio Profitabilitas, Rasio Aktivitas, Dan Ukuran Perusahaan Terhadap Pertumbuhan Laba. Jurnal Ilmu Dan Riset Manajemen, 7(6), 1-15.

Aryanto, U. R., Titisari, K. H., \& Nurlaela, S. (2018). Pengaruh Likuiditas, Leverage, Profitabilitas, dan Aktivitas Terhadap Pertumbuhan Laba. Seminar Nasional 44 
IENACO, (ISSN 2337-4349), 625-631.

Brigham, Eugene F. dan Houston, Joel F. 2011. Dasar-dasar Manajemen Keuangan Terjemahan. Edisi 10. Jakarta: Salemba Empat.

Erawati, T. (2019). Pengaruh Corporate Governance, Ukuran Perusahaan, Dan Leverage Terhadap Kinerja Keuangan Perusahaan Di Bursa Efek Indonesia ( Studi Kasus Perusahaan Manufaktur Yang Terdaftar di Bursa Efek Indonesia Periode 2013-2017 ). Jurnal Akuntansi Pajak Dewantara, 1(2), 129-137. https://doi.org/10.24964/japd.v1i1.895

Fatima, A. Z. (2020). Pengaruh Profitabilitas, Kepemilikan Saham Publik, dan Pertumbuhan Perusahaan Terhadap Internet Financial Reporting (IFR).

Nyale, M. H. (2020). Pengaruh Leverage, Cashflow Dan Working Moderating Pada Perusahaan Jasa Transportasi Yang Tercatat Di Bursa Efek Indonesia Tahun 2013 2016. Forum Ilmiah, 17(1), 1-20.

Panjaitan, R. J. (2018). Pengaruh Current Ratio, Debt To Equity Ratio, Net Profit Margin dan Return on Asset Terhadap Pertumbuhan Laba Pada Perusahaan Consumer Godds Yang Terdaftar Di BUrsa Efek Indonesia Periode 2013-2016. Jurnal Manajemen $V, 4(1), 61-72$.

Purwanti, D. (2021). Determinasi Kinerja Keuangan Perusahaan: Analisis Likuiditas ,Leverage Dan Ukuran Perusahaan (Literature Review Manajemen Keuangan). Jurnal Ilmu Manajemen Terapan, 2(5), 692-698. https://doi.org/doi.org/10.31933/jimt.v2i5

Sandjaja, A. E., \& Suwaidi, R. A. (2021). Pengaruh Likuiditas, Leverage, dan Rasio Aktivitas Terhadap Pertumbuhan Laba Pada Perusahaan Food and Beverages Yang Terdaftar Di BUrsa Efek Indonesia. Jurnal Sosial Ekonomi Dan Politik, 2(3), 1725.

Sari, K. A. N. S., \& Sudjarni, L. K. (2015). Pengaruh Likuiditas, Leverage, Pertumbuhan Perusahaan, dan profitabilitas Terhadap Kebijakan Dividen Pada Perusahaan Manufaktur di BEI. E-Jurnal Manajemen Unud, 4(10), 3346-3374.

Syafril, R., \& Djawoto. (2020). Pengaruh Rasio Likuiditas Solvabilitas, dan Aktivitas Terhadap Petumbuhan Laba. Jurnal Ilmu Dan Riset Manajemen, 9(7), 1-16.

Syahdeni, R., \& Hrp, A. P. (2021). Analisis Rasio Likuiditas dan Rasio Aktivitas Dalam Memprediksi Pertumbuhan Laba Pada BPJS Ketenagakerjaan Cabang Medan Kota. Jurnal Akuntansi Audit Dan Perpajakan Indonesia, 2(1). Retrieved from 45 
https://jurnal-lp2m.umnaw.ac.id/index.php/JAAPI/article/view/742

Tibiletti, V., Marchini, P. L., Gamba, V., \& Todaro, D. L. (2021). The Impact of COVID19 on Financial Statements Results and Disclosure: First Insights from Italian Listed Companies. Universal Journal of Accounting and Finance, 9(1), 54-64. https://doi.org/10.13189/ujaf.2021.090106

Ulinnuha, H. H., Mawardi, M. C., \& Mahsuni, A. W. (2020). Pengaruh Rasio Aktivitas, Rasio Leverage, dan Rasio Pertumbuhan Perusahaan Dalam Memprediksi Financial Distres (Studi pada Perusahaan Manufaktur yang Terdaftar di Bursa Efek Indonesia Periode 2016-2018). E-JRA, 09(03), 100-110.

Virgianthi, N. W. E. S., Yuesti, A., \& Dewi, N. P. S. (2019). Pengaruh Rasio Likuiditas, Solvabilitas, Aktivitas, dan Profitabilitas Terhadap Pertumbuhan Laba Pada Perusahaan Sektor Infrastruktur, Utilitas dan Transportasi Yang Terdaftar di Bursa Efek Indonesia. Seminar Nasional INOBALI, 896-903. 